\title{
Plankton trophic structure and particulate organic carbon production during a coastal downwelling-upwelling cycle
}

\author{
Mariana Guenther ${ }^{1,4, *}$, Eliane Gonzalez-Rodriguez ${ }^{2}$, Wanderson F. Carvalho ${ }^{2}$, \\ Carlos E. Rezende ${ }^{3}$, Glenda Mugrabe ${ }^{1}$, Jean L. Valentin ${ }^{1}$ \\ ${ }^{1}$ Laboratório de Zooplâncton, Departamento de Biologia Marinha, Instituto de Biologia, \\ Universidade Federal do Rio de Janeiro, Av. Brigadeiro Trompovsky s/n, Rio de Janeiro, RJ-CEP: 21949-900, Brazil \\ ${ }^{2}$ Departamento de Oceanografia, Instituto de Estudos do Mar Almirante Paulo Moreira, Comando da Marinha, \\ Rua Kioto 253, Arraial do Cabo, RJ-CEP: 28930-000, Brazil \\ ${ }^{3}$ Laboratório de Ciências Ambientais, Centro de Biociências e Biotecnologia, Universidade Estadual do Norte Fluminense, \\ Av. Alberto Lamego 2000, Campos dos Goytacazes, RJ-CEP: 28013-602, Brazil \\ ${ }^{4}$ Present address: Departamento de Biologia, Instituto de Ciências Biológicas, Universidade de Pernambuco, \\ Rua Arnóbio Marques 310, Recife, PE-CEP:500100-130, Brazil
}

\begin{abstract}
We evaluated plankton trophic structure in a short-term temporal survey performed throughout a downwelling-upwelling cycle at the SE Brazilian coast. Size-fractioned phytoplankton biomass (PB), microzooplankton (MiZA) and mesozooplankton (MeZA) abundances along with primary (PP) and bacterial production (BP) were estimated for 5 consecutive days at a fixed station in the Cabo Frio upwelling core area. During the downwelling period, the dominance of pico- and nanoplankton in $\mathrm{PB}$, and higher BP $\left(0.1 \mu \mathrm{g} \mathrm{C}^{-1} \mathrm{~h}^{-1}\right)$ and MiZA (170 ind. $\mathrm{l}^{-1}$ ), characterized a microbial food web structure. After the South Atlantic Central Water (SACW) upwelling, the decrease in BP $\left(0.02 \mu \mathrm{g} \mathrm{C}^{-1} \mathrm{~h}^{-1}\right)$, MiZA (50 ind. $\left.\mathrm{l}^{-1}\right)$ and picoplankton contribution to PB, along with the appearance of microplankton in $\mathrm{PB}$ and the increase in opportunistic herbivorous copepods densities (Paracalanus parvus: 2.0 ind. $^{-1}$ ) indicated the establishment of a herbivorous food web structure. Particulate organic carbon (POC) production was mainly due to phytoplankton (98\%) and did not differ between periods. However, the observed variability in plankton trophic interactions should affect the magnitude of POC export from this dynamic system.
\end{abstract}

KEY WORDS: Food webs · Carbon fluxes · Bacterioplankton - Phytoplankton · Zooplankton · Cabo Frio · South Brazil Bight

Resale or republication not permitted without written consent of the publisher

\section{INTRODUCTION}

Plankton trophic structure is mainly determined by the hydrodynamics and nutritional characteristics of the water column and directly affects the carbon cycle within pelagic ecosystems. In oligotrophic and stratified systems, primary production is based on small phytoplankton (Li \& Platt 1987). These cells present a higher surface:volume (S:V) ratio and thus lower sinking rates, remaining longer in suspension at the eu- photic zone (Guenther \& Bozelli 2004). For the same reason, they are also able to survive under low nutrient conditions, due to a high nutrient absorption efficiency; however, they have a low storage capacity and, hence, require constant nutrient supply (Malone 1980). In such systems, heterotrophic picoplankton play an important role as continuous nutrient suppliers via phytoplankton-released dissolved organic matter (DOM) oxidation (Lancelot 1979). The transfer of the particulate organic carbon (POC) produced by both 
small phytoplankton and bacteria to larger zooplankton and then higher pelagic trophic levels is mediated by heterotrophic nano- and micro-sized protists (Sherr et al. 1986). Therefore, in these microbial food webs, most of the biogenic carbon produced is recycled within the system through heterotrophic respiration (Legendre \& Le Fevre 1995).

In contrast, in more eutrophic systems with low vertical stability, larger phytoplankton cells are more representative and usually dominant, where turbulence simultaneously provides nutrient and prevents sinking below the euphotic zone (Kiørboe 1993). In those conditions an herbivorous food web prevails and most of the POC produced is exported via grazing, as the mesozooplankton are the dominant primary consumers (Legendre \& Rassoulzadegan 1996). Moreover, carbon export is directly related to the input and uptake of 'new' nutrients, mainly nitrate $\left(\mathrm{N}-\mathrm{NO}_{3}\right)$ to the euphotic zone (Dugdale \& Goering 1967), and this nitrogen form is primarily utilized by larger cells, such as diatoms (Price et al. 1985).

Coastal waters influenced by upwelling are among the most productive aquatic systems. The periodical wind-driven transport of surface waters offshore and the consequent upwelling of deeper water masses provide enrichment to previously oligotrophic waters. The high nutrient input to the surface waters, especially $\mathrm{N}-\mathrm{NO}_{3}$, stimulates phytoplankton production, mainly for larger species, resulting in higher mesozooplankton and fisheries productivity. This pattern has been described for several upwelling zones around the world, such as those in the SE Pacific Ocean (Peterson et al. 1988, Iriarte \& Gonzalez 2004, Fernandez-Alamo \& Farber-Lorda 2006), NE Pacific Ocean (Peterson et al. 1979, Collins et al. 2003), NE Atlantic Ocean (Bode et al. 2003), and Indian Ocean (Brown et al. 2002).

Upwelling zones usually occur along eastern ocean boundaries, between $30^{\circ} \mathrm{N}$ and $30^{\circ} \mathrm{S}$, due to the dominance of the trade winds. In the SW Atlantic, however, the change in the coastal direction at $23^{\circ} \mathrm{S}$ (Cabo Frio, SE Brazil) from N-S to E-W, along with the proximity of the $100 \mathrm{~m}$ isobath to the coast, allow the NE winds to move surface waters offshore and the consequent upwelling of the South Atlantic Central Water (SACW). This results in a high productivity core in the midst of the otherwise oligotrophic Brazilian Current waters (Valentin 1984a). The upwelling of deeper water masses is reversed when shifts in wind direction bring surface water back to the coast, with the consequent downwelling of those previously upwelled waters. In most regions, these upwelling-downwelling cycles occur on a seasonal (e.g. Brown et al. 2002, Collins et al. 2003, Cuevas et al. 2004) or even annual basis (e.g. Iriarte \& Gonzalez 2004). In Cabo Frio, however, the regular passage of cold fronts with SW winds produces relatively short cycles-from a few days to a few weeks (Valentin 1984a). Therefore this region experiences high variability in water column stability and nutrient dynamics (Gonzalez-Rodriguez et al. 1992), which may interfere with phytoplankton size distribution, affect the whole plankton trophic structure, and influence the magnitude of carbon export.

The aim of this study was thus to use a short-term temporal survey to quantify POC production and the relative contribution of each plankton component to the food web (i.e. size-fractioned phytoplankton, bacterioplankton, micro- and mesozooplankton), in order to evaluate the effects of upwelling events on the plankton trophic interactions.

\section{MATERIALS AND METHODS}

Study area. The Cabo Frio upwelling system is characterized by a combination of 3 different water masses: Brazil Current Tropical Water (TW; temperature [T] > $20^{\circ} \mathrm{C}$, salinity $\left.[S]>36\right)$, Coastal Water $\left(\mathrm{CW} ; T>20^{\circ} \mathrm{C}\right.$, $S<35$ ) and South Atlantic Central Water (SACW: $T<$ $20^{\circ} \mathrm{C}, S=34.5$ to 36$)$. The climate oscillation between cold fronts with SW winds and high precipitation, and inter-frontal phases with NE winds and low precipitation, establishes a large temporal and spatial variability in its physical and chemical characteristics (Valentin 1984a). The fixed station where the present study was conducted is located at the southern end of Cabo Frio Island $\left(23^{\circ} 00^{\prime} 57^{\prime \prime} \mathrm{S}, 42^{\circ} 00^{\prime} 09^{\prime \prime} \mathrm{W}\right)$, where the Brazilian coast changes its direction from $\mathrm{N}-\mathrm{S}$ to $\mathrm{E}-\mathrm{W}$ and the continental shelf is narrower, being thus the core of the SACW upwelling (Fig. 1).

Experimental design. Water samples for dissolved oxygen (DO), nutrients, dissolved organic carbon and nitrogen (DOC and DON), phytoplankton biomass $(\mathrm{PB})$, primary production (PP), bacterial production (BP) and microzooplankton abundance (MiZA) were collected with Niskin bottles (10 l) at the surface and below the thermocline $(40 \mathrm{~m})$, at $6 \mathrm{~h}$ intervals over 5 consecutive days (February 19 to 24, 2002) aboard the RV 'Diadorim' (Instituto de Estudos do Mar Almirante Paulo Moreira). Mesozooplankton samples were obtained through $40 \mathrm{~m}$ vertical hauling with a conical, $200 \mu \mathrm{M}$ mesh net, at $12 \mathrm{~h}$ intervals. Temperature, salinity, density and irradiance profiles were simultaneously obtained using a Seabird Seacat 19 CTD system.

Sample analyses. DO concentrations were estimated on board following Winkler titration (Aminot \& Chaussepied 1983). Samples for nutrients were immediately GF/F filtered $(\sim 0.7 \mu \mathrm{m})$ and frozen on board. At the laboratory, nutrient concentrations were determined following the methods proposed by Grasshoff et al. (1983) for nitrite $\left(\mathrm{N}-\mathrm{NO}_{2}\right), \mathrm{N}-\mathrm{NO}_{3}$, phosphate 

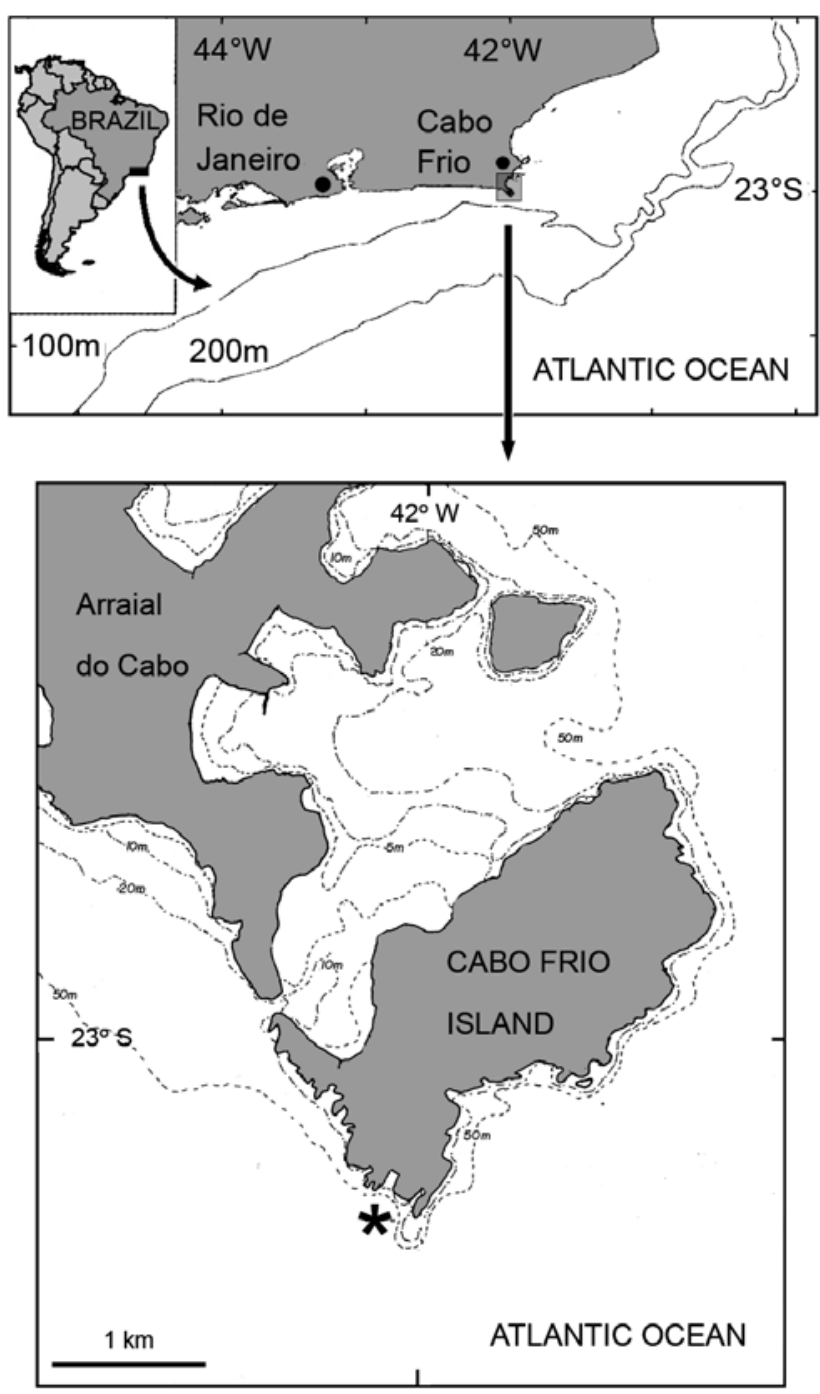

Fig. 1. Study area and fixed sampling station $(*)$

$\left(\mathrm{P}-\mathrm{PO}_{4}\right)$ and silicate $\left(\mathrm{Si}-\mathrm{SiO}_{4}\right)$ and those of Parsons et al. (1984) for ammonium $\left(\mathrm{N}-\mathrm{NH}_{4}\right)$.

Samples for DOC and DON analysis were GF/F filtered through pre-combusted $\left(450^{\circ} \mathrm{C}\right.$ for $\left.3 \mathrm{~h}\right)$ filters, preserved in phosphoric acid $\left(10 \% \mathrm{H}_{3} \mathrm{PO}_{4}\right)$ and refrigerated in amber bottles on board. DOC analyses were performed on the filtrates after further sample acidification $(2 \mathrm{~N} \mathrm{HCl})$ and sparing with ultra-pure air, by high temperature catalytic oxidation with a TOC-5000 Shimadzu Total Carbon Analyzer. Total dissolved nitrogen (TDN) was determined after digestion of the filtrates with potassium persulphate. DON was calculated by subtraction of the sum of nitrogen inorganic forms (N-NO $\mathrm{N}_{3} \mathrm{~N}-\mathrm{NO}_{2}$ and $\mathrm{N}-\mathrm{NH}_{4}$ ) from TDN.

Size-fractioned PB was obtained through successive filtration through $20 \mu \mathrm{m}$ net, $2.0 \mu \mathrm{m}$ polycarbonate membranes and $0.45 \mu \mathrm{m}$ cellulose membranes, which were stored in cryogenic vials in liquid nitrogen on board. At the laboratory, chlorophyll a (chl a) concentrations were determined after $18 \mathrm{~h}$ acetone $90 \%$ extraction at $4^{\circ} \mathrm{C}$ according to Parsons et al. (1984).

PP was estimated using the ${ }^{14} \mathrm{C}$ uptake method (Steemann-Nielsen 1952). Samples were incubated in situ in $60 \mathrm{ml}$ polycarbonate bottles (2 light and 1 dark) with $10 \mu \mathrm{Ci} \mathrm{NaH}{ }^{14} \mathrm{CO}_{3}$. At the end of $3 \mathrm{~h}$ incubations, samples were filtered through $0.45 \mu \mathrm{m}$ cellulose membranes, which were placed in scintillation vials and stored frozen on board. In the laboratory, $1.0 \mathrm{ml}$ of $1 \mathrm{M} \mathrm{HCl}$ was added to the vials for removal of ${ }^{14} \mathrm{CO}_{2}$ not incorporated within $12 \mathrm{~h}$ evaporation. After addition of scintillation liquid, isotopic activity was determined using a Packard Tricarb 1600 TR liquid scintillation counter, with internal calibration and quench correction. Total phytoplankton photosynthetic efficiency $\left(\mathrm{P}^{\mathrm{B}}\right)$ was calculated as PP/PB.

BP was assessed following Smith \& Azam (1992). Triplicate samples $(1.7 \mathrm{ml})$ were incubated for $1 \mathrm{~h}$ in sterile, $2 \mathrm{ml}$ screwcap tubes with $\mathrm{L}-\left[4,5-{ }^{3} \mathrm{H}\right]$ leucine (Amersham TRK 510; specific activity: $171 \mathrm{Ci} \mathrm{nmol}^{-1}$ ) at a $10 \mathrm{nM}$ final concentration. One tube was amended with $90 \mu \mathrm{l} 100 \%$ ice-cold trichloroacetic acid (TCA) as a killed control. The incubations were performed in separate thermal boxes, one for each sample depth, in order to preserve in situ temperatures. After $1 \mathrm{~h}$, the incubation was halted by addition of TCA and the tubes were immediately frozen on board. In the laboratory, samples were processed and the isotopic activity was determined using a Packard Tricarb 1600 TR liquid scintillation counter, with internal calibration and quench correction. Bacterial carbon production was calculated using a protein/carbon conversion factor of 0.86 (Simon \& Azam 1989).

Data on microzooplankton (20 to $200 \mu \mathrm{m}$ ) abundance were obtained from Purcell (2005). The water samples were preserved in $2 \%$ buffered paraformaldehyde at $5^{\circ} \mathrm{C}$ (Sherr \& Sherr 1993) and the individuals were enumerated under an inverted microscope according to Utermöhl (1958).

Mesozooplankton samples were preserved in $4 \%$ buffered paraformaldehyde on board (Griffiths et al. 1976) and species identification was based on Boltovskoy (1999).

Data analyses. Differences within each variable at each hydrological period (downwelling and upwelling) and layer (surface and $40 \mathrm{~m}$ ) were tested using an ANOVA followed by a Tukey's post-hoc multiple-comparison test. The relationships between the plankton compartments and several selected predictor variables were analyzed through both linear and standard (including intercept) forward-stepwise multiple regression. The model was executed with tolerance $>0.10$ and residual statistics were computed in order to iden- 
tify any extreme outliers. When one or several cases fell outside \pm 3 times the residual limit's standard deviation, the respective cases were excluded and the analysis ran over. Data normality was tested using a Kolmogorov-Smirnov test and a $\log (x)$ transform was applied in case of violation of this assumption. All tests were performed using Statistica version 7.0 (Statsoft). Mesozooplankton diversity was estimated using the Shannon-Wiener diversity index $H^{\prime}$ (Shannon 1948).

\section{RESULTS}

\section{Hydrology}

The variation in water column thermohaline structure and wind direction indicates that the study period covered both downwelling and upwelling periods (Table 1, Figs. 2 to 4). During the first $24 \mathrm{~h}$, temperature ranged from $24^{\circ} \mathrm{C}$ at the surface to $15^{\circ} \mathrm{C}$ below $30 \mathrm{~m}$, forming a thermocline at that depth. In the next $24 \mathrm{~h}$, surface temperatures decreased, reaching $17^{\circ} \mathrm{C}$ at time $(t)=48 \mathrm{~h}$, then slightly re-warmed by $t=72 \mathrm{~h}$ $\left(19\right.$ to $\left.20^{\circ} \mathrm{C}\right)$. At $40 \mathrm{~m}$, temperature also decreased from $15^{\circ} \mathrm{C}$ during the first $36 \mathrm{~h}$ to $13-14^{\circ} \mathrm{C}$ afterwards. Salinity was homogeneous throughout the water column ( 35 to 35.5$)$, except for the first $3 \mathrm{~m}$ during the first $18 \mathrm{~h}$, when salinity reached 33.5 (Fig. 2b). The 24.5 isopycnal, SACW lower density limit (Silva et al. 2005), rose from $15 \mathrm{~m}$ to the surface at $t=36 \mathrm{~h}$ (Fig. 2c). The dominance of SW winds $\left(\sim 5.0 \mathrm{~m} \mathrm{~s}^{-1}\right) 5 \mathrm{~d}$ before the beginning of the study favored the maintenance of the surface water (TW and CW) near the coast (downwelling). The shift to stronger NE winds $\left(\sim 10.0 \mathrm{~m} \mathrm{~s}^{-1}\right)$ at the beginning of the study period (February 19) through the following $48 \mathrm{~h}$ carried the surface water out of the coast, allowing the deeper SACW to move up to the surface by the third sampling day (February 21) (Fig. 3). A $T$ - $S$ diagram designed with surface and $40 \mathrm{~m}$ data confirms a mixing between the TW and CW during the first $36 \mathrm{~h}$ study at the surface (i.e. downwelling) and dominance by the SACW afterwards. The $40 \mathrm{~m}$ layer was filled with the SACW throughout the whole period (Fig. 4).
Nutrient, DO and DOM dynamics followed this hydrological variation (Table 1, Fig. 5). At the surface, except for $\mathrm{N}-\mathrm{NH}_{4}$, which was variable but equivalent in both periods $(\sim 1.0 \mu \mathrm{M})$, the remaining nutrient concentrations increased with the SACW upwelling $\left(\mathrm{N}-\mathrm{NO}_{2}=0.2 \mu \mathrm{M}, \mathrm{N}^{-\mathrm{NO}_{3}}=3.4 \mu \mathrm{M}, \mathrm{P}-\mathrm{PO}_{4}=0.5 \mu \mathrm{M}\right.$, $\mathrm{Si}_{-} \mathrm{SiO}_{4}=4.3 \mu \mathrm{M}$ ). At $40 \mathrm{~m}$, no significant differences between periods were observed, except for $\mathrm{N}-\mathrm{NO}_{2}$ concentrations, which decreased with the SACW upwelling, from 0.34 to $0.23 \mu \mathrm{M}$. DO concentrations decreased at the surface from $6.4 \mathrm{ml} \mathrm{l}^{-1}$ at the downwelling period, to $5.1 \mathrm{ml} \mathrm{l}^{-1}$ after the SACW upwelling, similar to the DO levels observed at $40 \mathrm{~m}$ during the whole study period $\left(\sim 4.7 \mathrm{ml} \mathrm{l}^{-1}\right)$. DOC concentrations were variable in both layers, ranging between 68 and $269 \mu \mathrm{M}$, while DON concentrations, less variable, ranged from 2.3 to $5.1 \mu \mathrm{M}$ in both layers. The DOM C:N oscillated between 20 and 60 in both layers, following DOC oscillation. No significant differences between phases or layers were observed for those variables.

\section{Phytoplankton}

PB increased at the surface from $2.3-3.5$ to $6.3 \mu \mathrm{g}$ chl $a \mathrm{l}^{-1}$ after the SACW upwelling (Fig. 6). The highest $\mathrm{PB}$ values during the upwelling period were detected

Table 1. Mean values and standard deviations (in parentheses) of the variables at both layers and hydrological periods. Treatments with the same letter are not significantly different from each other (Tukey's multiple comparison test following an ANOVA, $\mathrm{p}<$ 0.05). Mesozooplankton abundance (MeZa) was determined through $40 \mathrm{~m}$ vertical hauling so there was no distinction between layers. Microzooplankton abundance (MiZA) data were obtained from Purcell (2005). See 'Materials and methods' for definitions of abbreviations

\begin{tabular}{|c|c|c|c|c|}
\hline & \multicolumn{2}{|c|}{${ }_{\text {Surface }}-$} & \multicolumn{2}{|c|}{$-40 \mathrm{~m}$} \\
\hline & Downwelling & Upwelling & Downwelling & Upwelling \\
\hline Temperature $\left({ }^{\circ} \mathrm{C}\right)$ & $24.4^{\mathrm{a}}(0.43)$ & $19.4^{\mathrm{b}}(0.99)$ & $15.2^{\mathrm{c}}(0.24)$ & $13.8^{\mathrm{d}}(0.20)$ \\
\hline Salinity & $34.9^{\mathrm{a}}(0.65)$ & $35.4^{\mathrm{a}}(0.20)$ & $35.5^{\mathrm{a}}(0.08)$ & $35.4^{\mathrm{a}}(0.10)$ \\
\hline Density $\left(\sigma_{t}\right)$ & $23.4^{\mathrm{c}}(0.56)$ & $25.2^{\mathrm{b}}(0.30)$ & $26.5^{\mathrm{a}}(0.10)$ & $26.7^{\mathrm{a}}(0.08)$ \\
\hline $\mathrm{N}-\mathrm{NH}_{4}(\mu \mathrm{M})$ & $0.96^{\mathrm{a}}(0.17)$ & $1.41^{\mathrm{a}}(0.41)$ & $1.03^{\mathrm{a}}(0.20)$ & $1.06^{\mathrm{a}}(0.26)$ \\
\hline $\mathrm{N}-\mathrm{NO}_{2}(\mu \mathrm{M})$ & $0.03^{\mathrm{c}}(0.01)$ & $0.23^{b}(0.08)$ & $0.34^{\mathrm{a}}(0.07)$ & $0.23^{\mathrm{b}}(0.06)$ \\
\hline $\mathrm{N}-\mathrm{NO}_{3}(\mu \mathrm{M})$ & $0.34^{\mathrm{c}}(0.08)$ & $3.36^{\mathrm{b}}(1.66)$ & $5.98^{\mathrm{a}, \mathrm{b}}(1.19)$ & $8.14^{\mathrm{a}}(0.90)$ \\
\hline $\mathrm{P}-\mathrm{PO}_{4}(\mu \mathrm{M})$ & $0.18^{\mathrm{c}}(0.04)$ & $0.49^{b}(0.09)$ & $0.54^{\mathrm{a}}(0.23)$ & $0.71^{\mathrm{a}}(0.08)$ \\
\hline $\mathrm{Si}-\mathrm{SiO}_{4}(\mu \mathrm{M})$ & $2.22^{\mathrm{c}}(0.71)$ & $4.26^{\mathrm{b}, \mathrm{c}}(1.43)$ & $6.19^{\mathrm{a}, \mathrm{b}}(0.97)$ & $6.27^{\mathrm{a}}(1.14)$ \\
\hline $\mathrm{DO}\left(\mathrm{ml} \mathrm{l}^{-1}\right)$ & $6.41^{\mathrm{a}}(0.78)$ & $5.09^{\mathrm{b}}(0.34)$ & $4.74^{\mathrm{b}}(0.60)$ & $4.62^{\mathrm{b}}(0.16)$ \\
\hline $\mathrm{DOC}(\mu \mathrm{M})$ & $174^{\mathrm{a}}(67.7)$ & $127^{a}(40.6)$ & $125^{\mathrm{a}}(33.5)$ & $143^{\mathrm{a}}(54.3)$ \\
\hline DON $(\mu \mathrm{M})$ & $4.09^{\mathrm{a}, \mathrm{b}}(0.54)$ & $3.06^{\mathrm{b}}(0.48)$ & $4.48^{\mathrm{a}}(0.44)$ & $3.47^{\mathrm{a}, \mathrm{b}}(0.71)$ \\
\hline DOM C:N & $41.8^{\mathrm{a}}(13.6)$ & $41.9^{\mathrm{a}}(13.5)$ & $28.3^{\mathrm{a}}(8.81)$ & $41.3^{\mathrm{a}}(12.6)$ \\
\hline PB $\left(\mu \mathrm{g} \mathrm{chl} \mathrm{a} \mathrm{l}^{-1}\right)$ & $3.24^{\mathrm{a}}(1.09)$ & $4.79^{\mathrm{a}}(1.14)$ & $4.59^{\mathrm{a}}(0.63)$ & $1.38^{\mathrm{b}}(0.82)$ \\
\hline $\mathrm{P}^{\mathrm{B}}\left(\mu \mathrm{gC} \mu \mathrm{g} \mathrm{chl} a^{-1} \mathrm{~h}^{-1}\right)$ & $2.05^{a}(1.06)$ & $1.29^{\mathrm{a}, \mathrm{b}}(0.46)$ & $0.63^{\mathrm{b}, \mathrm{c}}(0.51)$ & $0.39^{\mathrm{c}}(0.25)$ \\
\hline MiZA (ind. $\mathrm{ml}^{-1}$ ) & $175^{\mathrm{a}}(80.8)$ & $91.0^{\mathrm{a}, \mathrm{b}}(73.6)$ & $98.3^{\mathrm{a}, \mathrm{b}}(17.4)$ & $15.3^{\mathrm{b}}(6.54)$ \\
\hline MeZA (ind. $\mathrm{l}^{-1}$ ) & $2.84^{\mathrm{a}}(0.44)$ & $3.09^{\mathrm{a}}(0.58)$ & $2.84^{\mathrm{a}}(0.44)$ & $3.09^{\mathrm{a}}(0.58$ \\
\hline$P P\left(\mu g C^{-1} h^{-1}\right)$ & $6.51^{\mathrm{a}}(4.25)$ & $5.56^{\mathrm{a}}(1.91)$ & $3.15^{\mathrm{a}, \mathrm{b}}(2.79)$ & $0.48^{\mathrm{b}}(0.22)$ \\
\hline $\mathrm{BP}\left(\mu \mathrm{g} \mathrm{C} \mathrm{l}^{-1} \mathrm{~h}^{-1}\right)$ & $0.08^{\mathrm{a}}(0.04)$ & $0.04^{\mathrm{a}, \mathrm{b}}(0.02)$ & $0.04^{\mathrm{a}, \mathrm{b}}(0.02)$ & $0.01^{\mathrm{b}}(0.01)$ \\
\hline $\mathrm{BP} / \mathrm{PP}$ & $0.01^{\mathrm{b}}(0.01)$ & $0.01^{\mathrm{b}}(0.01)$ & $0.03^{\mathrm{a}}(0.03)$ & $0.02^{\mathrm{a}, \mathrm{b}}(0.01)$ \\
\hline
\end{tabular}



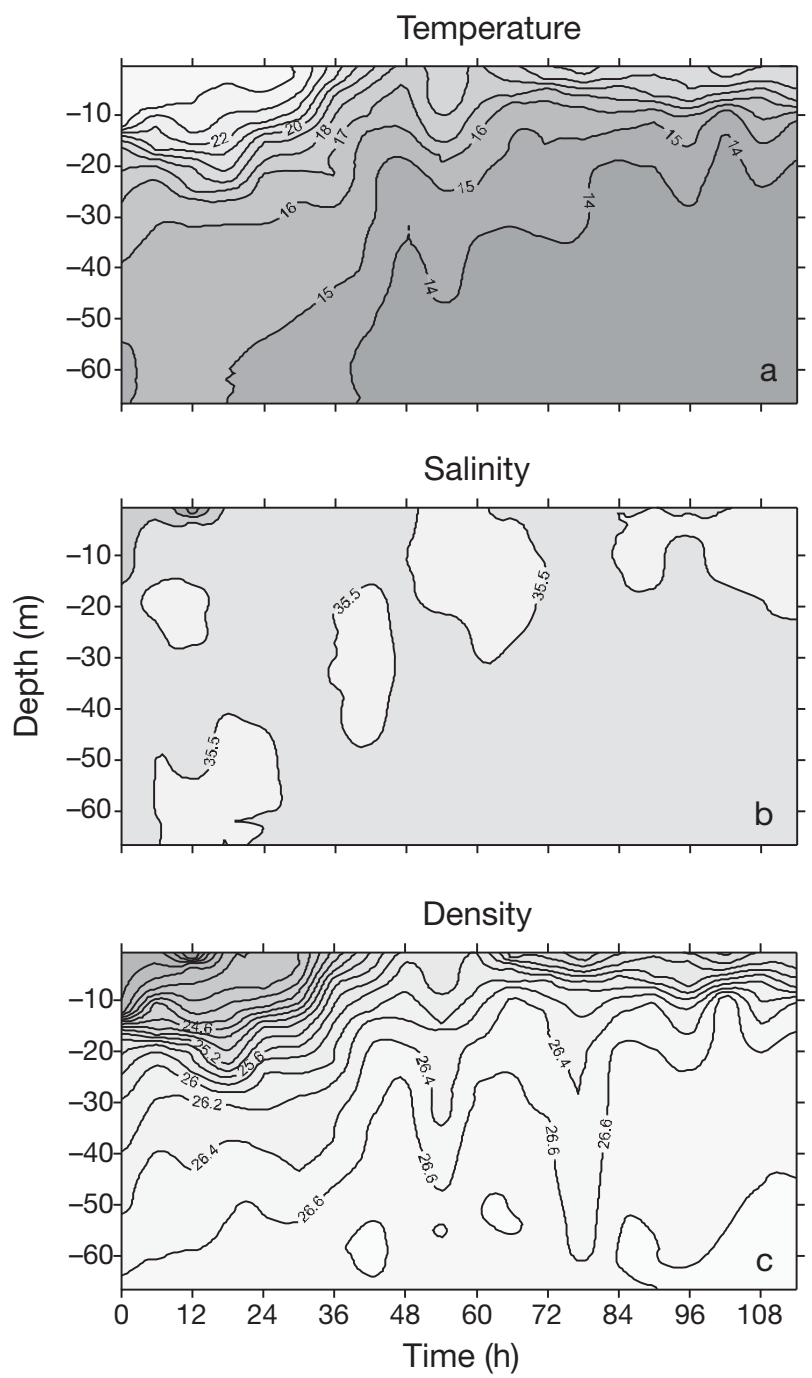

Fig. 2. (a) Isotherms $\left({ }^{\circ} \mathrm{C}\right)$, (b) isohalines, and (c) isopycnals $\left(\sigma_{t}\right)$

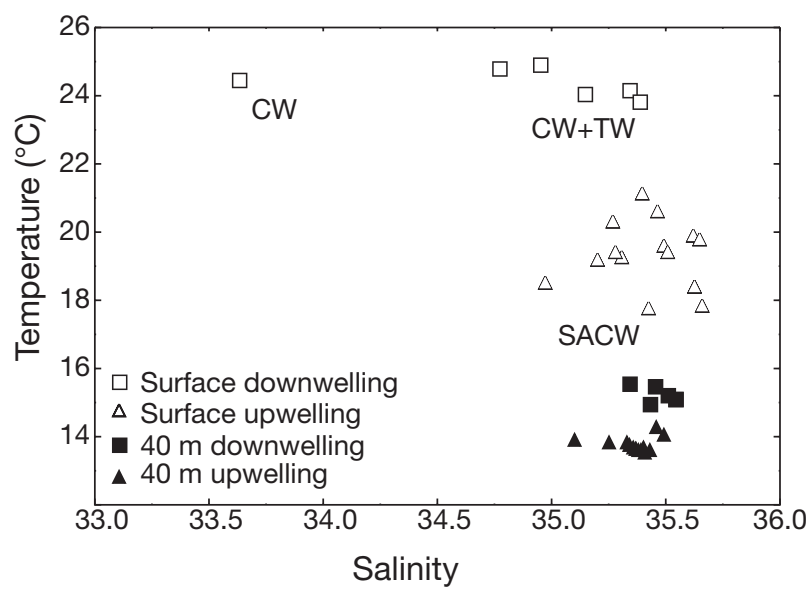

Fig. 4. Temperature ( $T$ ) vs. salinity $(S)$ diagram at the surface (open symbols) and $40 \mathrm{~m}$ (closed symbols). Coastal Water (CW): $T>20^{\circ} \mathrm{C}, S<35$; Brazil Current Tropical Water (TW): $T>20^{\circ} \mathrm{C}, S>36$; South Atlantic Central Water (SACW): $T<20^{\circ} \mathrm{C}, S=34.5$ to 36

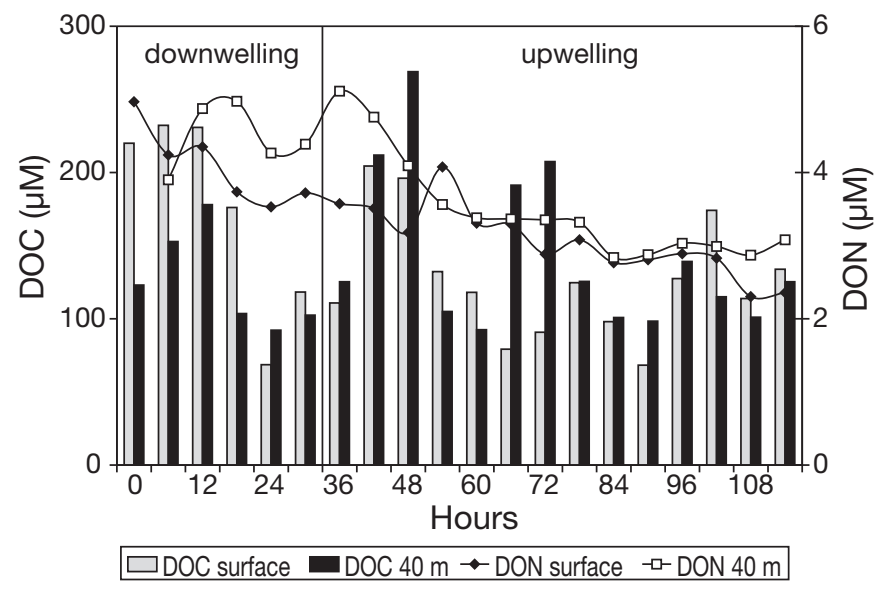

Fig. 5. Dissolved organic carbon (DOC) and nitrogen (DON) at the surface and $40 \mathrm{~m}$

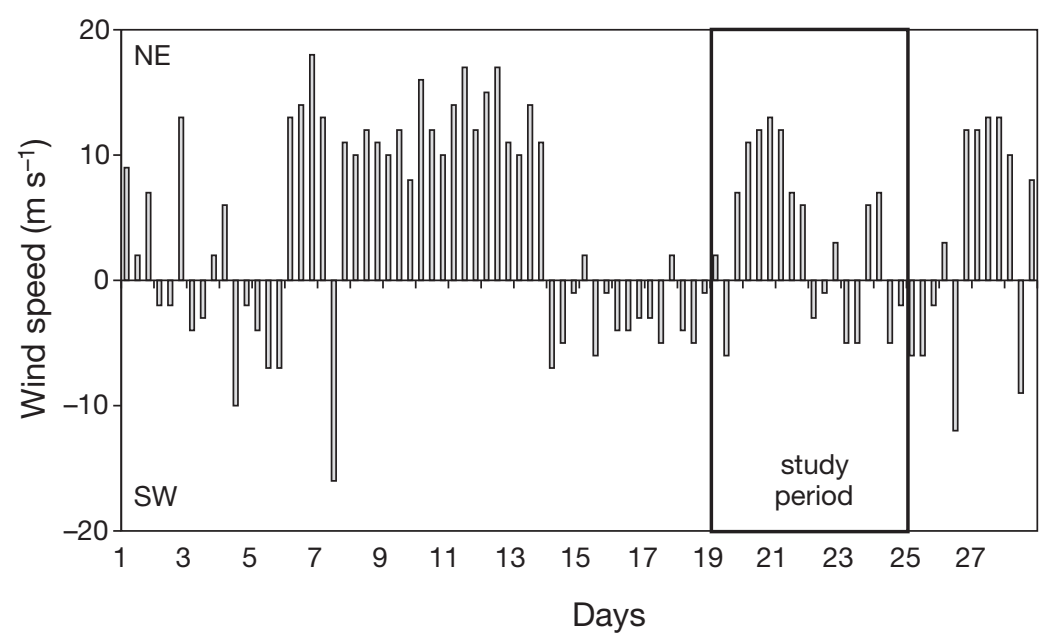

Fig. 3. Wind speed and direction during February 2002. Study period is boxed at night $(21: 00 \mathrm{~h})$ and the lowest in the morning (03:00 and 09:00 h). At $40 \mathrm{~m}$, $\mathrm{PB}$ decreased from $3.8-5.3$ to $0.5 \mu \mathrm{g}$ chl a $\mathrm{l}^{-1}$ after the SACW upwelling. Significant differences between periods were found only at $40 \mathrm{~m}$ (Table 1). The variation in $\mathrm{PB}$ at the surface $\left(\mathrm{R}^{2}=\right.$ 0.98) was directly dependent on concentrations of $\mathrm{N}-\mathrm{NH}_{4}(\beta=0.71), \mathrm{P}_{-} \mathrm{PO}_{4}$ $(\beta=0.49)$, DON $(\beta=0.44)$ and salinity $(\beta=0.30)$, while at $40 \mathrm{~m}, \mathrm{~PB}$ variation $\left(\mathrm{R}^{2}=0.99\right)$ was directly dependent on $\mathrm{N}-\mathrm{NO}_{2}(\beta=0.40)$, temperature $(\beta=0.34)$ and salinity $(\beta=0.13)$ and inversely dependent on $\mathrm{N}-\mathrm{NO}_{3}(\beta=-0.25)$ and $\mathrm{P}$ $\mathrm{PO}_{4}(\beta=-0.21)$ (Table 2). 


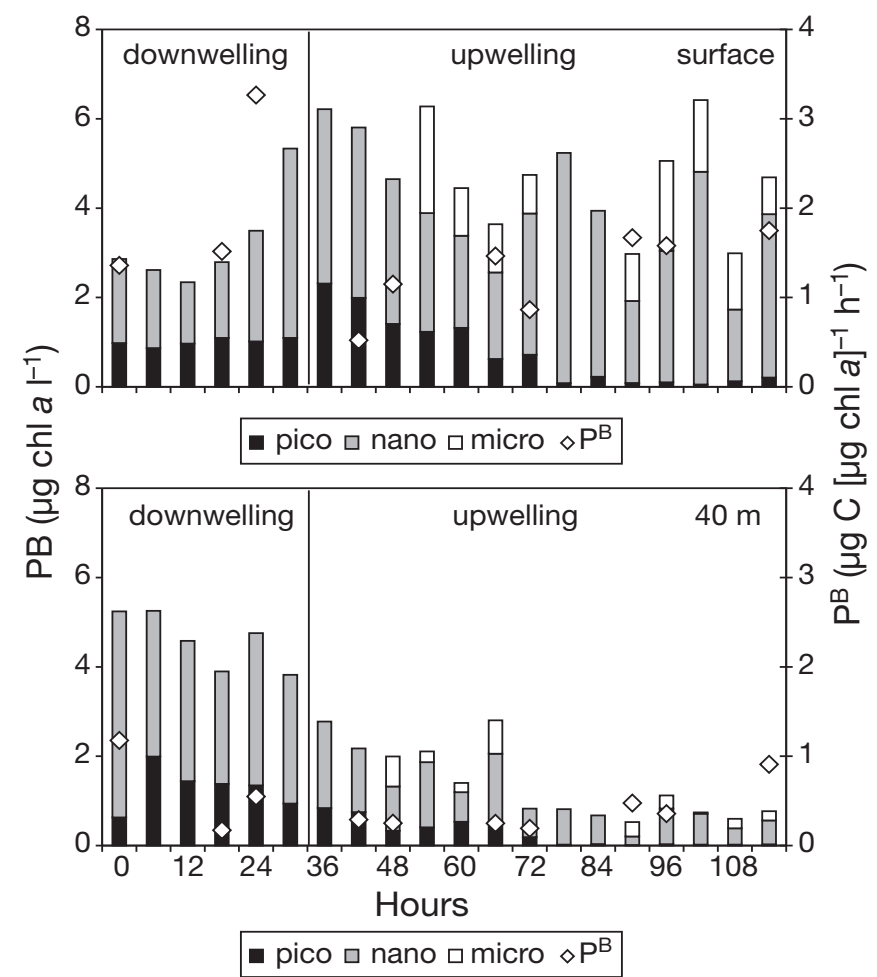

Fig. 6. Phytoplankton biomass (PB) of the 3 size classes and total phytoplankton photosynthetic efficiency $\left(\mathrm{P}^{\mathrm{B}}\right)$ at the surface and $40 \mathrm{~m}$
Nanoplankton was the dominant size fraction during the downwelling at both sampled layers, accounting for 59 to $79 \%$ at the surface and 62 to $88 \%$ at 40 m (Fig. 6). Picoplankton represented 21 to $44 \%$ of PB at the surface and 12 to $38 \%$ at $40 \mathrm{~m}$. No microplankton was registered during that period, appearing only $12 \mathrm{~h}$ after the SACW upwelling in both sampled layers, when it represented 18 to $42 \%$ of PB at the surface and 4 to $62 \%$ at $40 \mathrm{~m}$. Nanoplankton was still the dominant fraction during the upwelling period, representing 42 to $98 \%$ of PB at the surface and 36 to $97 \%$ at 40 m, while picoplankton contribution gradually decreased, from 40 to $1 \%$ in both layers.

$\mathrm{P}^{\mathrm{B}}$ at the surface ranged from 1.4 to $3.3 \mu \mathrm{g} \mathrm{C}(\mu \mathrm{g}$ chl a) ${ }^{-1} \mathrm{~h}^{-1}$ at the downwelling and 0.5 to $1.8 \mu \mathrm{g} \mathrm{C}$ $(\mu \mathrm{g} \mathrm{chl} \mathrm{a})^{-1} \mathrm{~h}^{-1}$ after the upwelling (Fig. 6). At $40 \mathrm{~m}$, $\mathrm{P}^{\mathrm{B}}$ was significantly lower during both periods (Table 1), ranging from 0.2 to $1.2 \mu \mathrm{g} \mathrm{C}(\mu \mathrm{g} \mathrm{chl} \mathrm{a})^{-1}$ $\mathrm{h}^{-1}$ at the downwelling and 0.3 to $0.9 \mu \mathrm{g} \mathrm{C}(\mu \mathrm{g}$ chl $a)^{-1} \mathrm{~h}^{-1}$ after the upwelling. The variations in $\mathrm{P}^{\mathrm{B}}$ $\left(\mathrm{R}^{2}=0.85\right)$ were directly dependent on temperature $(\beta=0.79)$ and inversely dependent on DON ( $\beta$ $=-0.42)$ and $\mathrm{N}-\mathrm{NH}_{4}(\beta=-0.28)$. Both layers were analyzed together due to the low sample size (Table 2).

Table 2. Multiple regression models: $\mathrm{R}^{2}, \beta$ and partial $\mathrm{r}$ values (in parentheses below $\beta$ values) for the plankton compartments variations with selected variables. None of the selected variables explained MeZA variations. For $\mathrm{P}^{\mathrm{B}}$ and $\mathrm{PP}$, both layers were analyzed together due to the low sample size. ${ }^{*} \mathrm{p}<0.05,{ }^{* *} \mathrm{p}<0.01,{ }^{* * *} \mathrm{p}<0.001 . \mathrm{x}$ : variable was not included in the model

\begin{tabular}{|c|c|c|c|c|c|c|c|c|c|}
\hline & & & \multirow{2}{*}{$\begin{array}{c}\text { - Surface } \\
\text { PP }\end{array}$} & \multirow[b]{2}{*}{$\mathrm{BP}$} & \multirow[b]{2}{*}{ MiZA } & \multirow{2}{*}{$\mathrm{PB} \quad \mathrm{P}^{\mathrm{B}}$} & \multirow{2}{*}{$\begin{array}{l}-40 \mathrm{~m} \\
\mathrm{PP}\end{array}$} & \multirow[b]{2}{*}{ BP } & \multirow[b]{2}{*}{ MiZA } \\
\hline & PB & $\mathrm{P}^{\mathrm{B}}$ & & & & & & & \\
\hline $\mathrm{R}^{2}$ & $0.98^{* * *}$ & $0.85^{* * *}$ & $0.76^{* * *}$ & $0.63^{* *}$ & $0.84^{* * *}$ & $0.99^{* * *}$ & & $0.94^{* * *}$ & $0.99^{* * *}$ \\
\hline$\beta\left(\mathrm{N}-\mathrm{NH}_{4}\right)$ & $\begin{array}{l}0.71^{* * *} \\
(0.97)\end{array}$ & $\begin{array}{l}-0.27^{*} \\
(-0.54)\end{array}$ & $\begin{array}{l}-0.33^{*} \\
(-0.57)\end{array}$ & & $\mathrm{x}$ & & & & $\mathrm{x}$ \\
\hline$\beta\left(\mathrm{N}-\mathrm{NO}_{2}\right)$ & & & $\begin{array}{l}0.72^{* *} \\
(0.78)\end{array}$ & & $\mathrm{x}$ & $\begin{array}{l}0.40^{* *} \\
(0.84)\end{array}$ & & $\begin{array}{l}0.77^{* * *} \\
(0.95)\end{array}$ & $\mathrm{x}$ \\
\hline$\beta\left(\mathrm{N}-\mathrm{NO}_{3}\right)$ & & & & & $\mathrm{x}$ & $\begin{array}{l}-0.26^{* *} \\
(-0.78)\end{array}$ & & & $\mathrm{x}$ \\
\hline$\beta\left(\mathrm{P}-\mathrm{PO}_{4}\right)$ & $\begin{array}{c}0.49^{*} \\
(0.76)\end{array}$ & & & & $\mathrm{x}$ & $\begin{array}{l}-0.21^{*} \\
(-0.68)\end{array}$ & & & $\mathrm{x}$ \\
\hline$\beta\left(\mathrm{Si}-\mathrm{SiO}_{4}\right)$ & & & & $\mathrm{x}$ & $\mathrm{x}$ & & & $\mathrm{x}$ & $\mathrm{x}$ \\
\hline$\beta$ (DOC) & & & & $\begin{array}{l}-0.67^{*} \\
(-0.62)\end{array}$ & $\mathrm{x}$ & & & & $\mathrm{x}$ \\
\hline$\beta(\mathrm{DON})$ & $\begin{array}{l}0.44^{* * *} \\
(0.90)\end{array}$ & $\begin{array}{l}-0.42^{* *} \\
(-0.69)\end{array}$ & $\begin{array}{l}-0.65^{* * *} \\
(-0.82)\end{array}$ & & $\mathrm{x}$ & & & & $\mathrm{x}$ \\
\hline$\beta(\mathrm{T})$ & & $\begin{array}{l}0.79^{* * *} \\
(0.89)\end{array}$ & $\begin{array}{l}0.73^{* *} \\
(0.70)\end{array}$ & & & $\begin{array}{l}0.34^{* *} \\
(0.76)\end{array}$ & & & $\begin{array}{l}0.69^{* * *} \\
(0.97)\end{array}$ \\
\hline$\beta(\mathrm{S})$ & $\begin{array}{l}0.30^{* *} \\
(0.86)\end{array}$ & & & & & $\begin{array}{c}0.13^{*} \\
(0.66)\end{array}$ & & $\begin{array}{l}0.27^{* *} \\
(0.64)\end{array}$ & $\begin{array}{l}0.12^{* *} \\
(0.80)\end{array}$ \\
\hline$\beta(\mathrm{PB})$ & $\mathrm{x}$ & $\mathrm{x}$ & $\mathrm{x}$ & & & $\mathrm{x}$ & & & $\begin{array}{l}0.28^{* * *} \\
(0.82)\end{array}$ \\
\hline$\beta(\mathrm{BP})$ & $\mathrm{x}$ & $\mathrm{x}$ & $\mathrm{x}$ & $\mathrm{x}$ & $\begin{array}{l}0.87^{* *} \\
(0.86)\end{array}$ & & & & \\
\hline
\end{tabular}




\section{Microzooplankton}

MiZA during downwelling ranged between 83 and 317 ind. $\mathrm{ml}^{-1}$ at the surface and between 84 and 130 ind. $\mathrm{ml}^{-1}$ at $40 \mathrm{~m}$ (Fig. 7). A steep decrease in MiZA was observed in both layers with the SACW upwelling: from 250 to 23 and 90 to 14 ind. $\mathrm{ml}^{-1}$ at the surface and $40 \mathrm{~m}$, respectively. A peak in MiZA was observed $42 \mathrm{~h}$ after the SACW upwelling (143 ind. $\mathrm{ml}^{-1}$ ), decreasing to 23-77 ind. $\mathrm{ml}^{-1}$ afterwards. At $40 \mathrm{~m}$, MiZA oscillated between 6 and 30 ind. $\mathrm{ml}^{-1}$ during the whole upwelling period. No significant differences were found between layers or periods (Table 1). The variation in MiZA at the surface $\left(R^{2}=0.84\right)$ was directly dependent on BP $(\beta=0.67)$ and at $40 \mathrm{~m}\left(\mathrm{R}^{2}=0.99\right)$ was directly dependent on temperature $(\beta=0.69)$, PB $(\beta=0.28)$ and salinity $(\beta=0.12)$ (Table 2$)$.

\section{Mesozooplankton}

MeZA ranged from 2.4 to 4.0 ind. $\mathrm{l}^{-1}$, with Copepoda as the dominant group in both downwelling and upwelling periods (70 and $94 \%$, respectively) and Paracalanus parvus as the most representative species (30 and $67 \%$, respectively) (Fig. 8). No significant differences were observed in total MeZA (Table 1), but the abundances of some species and their contribution to the mesozooplankton community varied between the hydrological periods. During the downwelling, the copepods P. parvus (0.8 to 1.0 ind. $\mathrm{l}^{-1}$ ) and Temora turbinata ( 0.4 to 0.6 ind. $^{-1}$ ) and the cladoceran Pseudevadne tergestina ( 0.4 to 0.8 ind. $\mathrm{l}^{-1}$ ) were the most representative species. After the SACW upwelling, we observed a decrease in the abundances of $T$. turbinata $(0.2$ to 0.4 ind. $\mathrm{l}^{-1}$ ) and P. tergestina ( 0.01 to 0.09 ind. $\mathrm{l}^{-1}$ ), an increase in the abundances of $P$. parvus (1.3 to 2.3 ind.

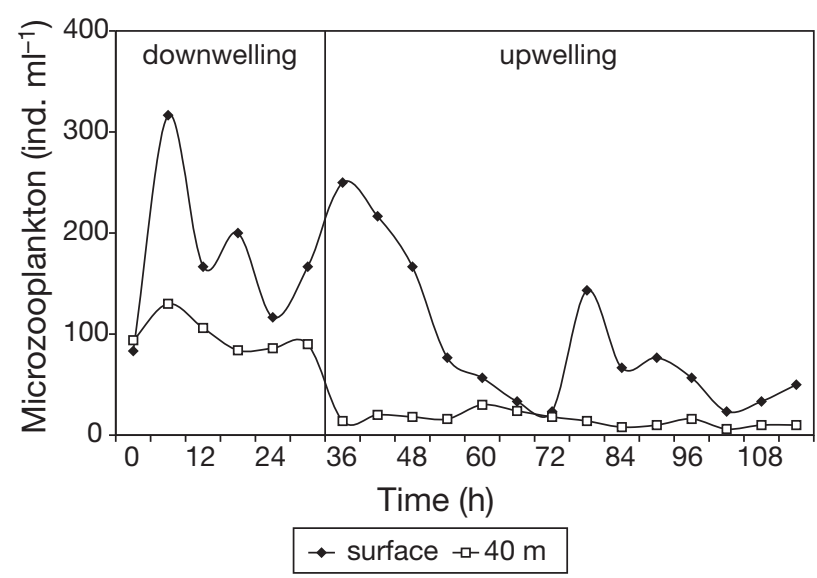

Fig. 7. Microzooplankton abundance at the surface and $40 \mathrm{~m}$ (adapted from Purcell 2005) $\mathrm{l}^{-1}$ ) and Ctenocalanus vanus (0.08 to 0.8 ind. $\mathrm{l}^{-1}$ ), and the appearance, although at low densities (0.04 to 0.2 ind. $\mathrm{l}^{-1}$ ), of Calanoides carinatus. The other mesozooplankton species represented less than $10 \%$ of total abundance, with no significant differences between hydrological periods. Mesozooplankton diversity declined from 3.0 to 3.2 bits ind. $^{-1}$ at the beginning of the downwelling period to 2.0 bits ind. $^{-1}$ after the SACW upwelling, due mainly to $P$. parvus dominance. None of the selected variables explained MeZA variations (Table 2).

\section{Particulate organic carbon production}

PP was equivalent in both layers during the downwelling but higher at the surface after the SACW upwelling (Table 1, Fig. 9). At the surface, PP ranged from 3.9 to 11.4 and 3.0 to $8.2 \mu g \mathrm{Cl}^{-1} \mathrm{~h}^{-1}$ during the downwelling and upwelling periods, respectively. At

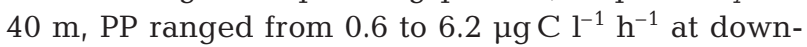
welling and 0.2 to $0.7 \mu \mathrm{g} \mathrm{C} \mathrm{l}^{-1} \mathrm{~h}^{-1}$ after the upwelling. The variations in PP $\left(R^{2}=0.88\right)$ were directly dependent on temperature $(\beta=0.73)$ and $\mathrm{N}-\mathrm{NO}_{2}(\beta=0.72)$ and inversely dependent on DON $(\beta=-0.65)$ and $\mathrm{N}-\mathrm{NH}_{4}(\beta=-0.33)$. Both layers were analyzed together due to the low sample size (Table 2).

$\mathrm{BP}$ rates increased in both layers during the downwelling period, from 0.02 to $0.13 \mu \mathrm{g} \mathrm{C}^{-1} \mathrm{~h}^{-1}$ at the surface and from 0.02 to $0.07 \mu \mathrm{C} \mathrm{l}^{-1} \mathrm{~h}^{-1}$ at $40 \mathrm{~m}$ (Fig. 9). A steep decrease in BP was observed in both layers with the SACW upwelling: from 0.13 to $0.02 \mu \mathrm{g} \mathrm{Cl}^{-1}$ $\mathrm{h}^{-1}$ and from 0.07 to $0.002 \mu \mathrm{g} \mathrm{Cl}^{-1} \mathrm{~h}^{-1}$ at the surface and $40 \mathrm{~m}$, respectively. An increase in BP was observed $42 \mathrm{~h}$ after the SACW upwelling at the surface

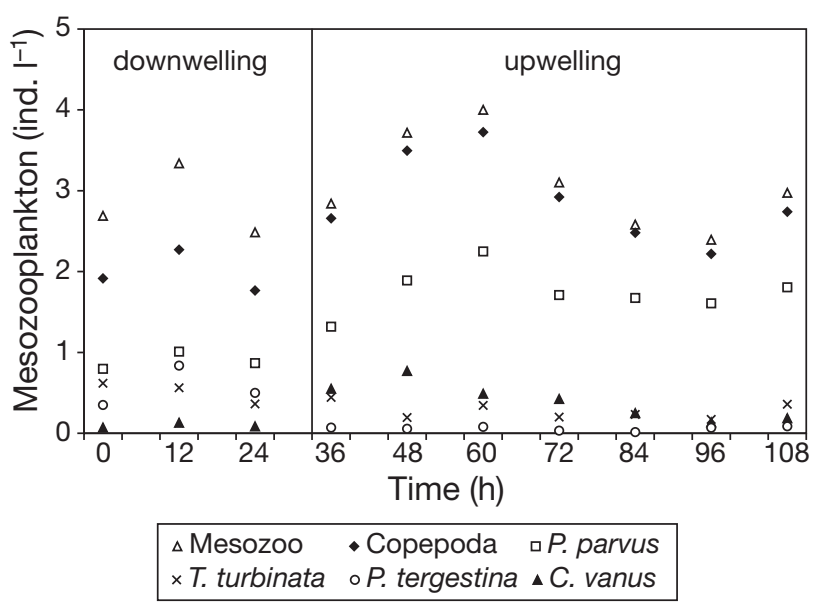

Fig. 8. Abundance of total mesozooplankton, total Copepoda, and the dominant species at the first $40 \mathrm{~m}$ depth: Paracalanus parvus, Ctenocalanus vanus, Temora turbinata and Pseudevadne tergestina 


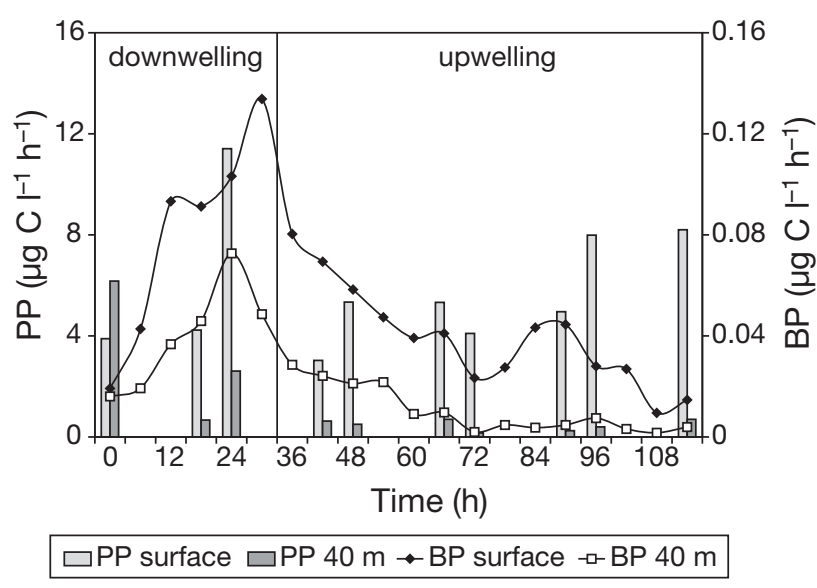

Fig. 9. Primary production (PP) and bacterial production (BP) at the surface and $40 \mathrm{~m}$

$\left(0.04 \mu \mathrm{C} \mathrm{C} \mathrm{l}^{-1} \mathrm{~h}^{-1}\right)$, decreasing afterwards. No significant differences were found between layers or periods (Table 1). BP represented $1 \%$ of PP at the surface and 2 to $3 \%$ at $40 \mathrm{~m}$. Significant differences in BP/PP rates were observed between layers at the downwelling period (Table 1). The variation in BP at the surface $\left(\mathrm{R}^{2}=0.63\right)$ was inversely dependent on DOC $(\beta=$ $-0.67)$ and at $40 \mathrm{~m}\left(\mathrm{R}^{2}=0.94\right)$ was directly dependent on $\mathrm{N}-\mathrm{NO}_{2}(\beta=0.77)$ and salinity $(\beta=0.27)$ (Table 2$)$.

\section{DISCUSSION}

Plankton trophic structure at the Cabo Frio upwelling was affected by circulation dynamics and the consequent variations in temperature and nutrients contents. During the downwelling, when temperature was higher, a microbial food web structure prevailed, with dominance by smaller phytoplankton (pico and nano) and higher contribution of bacterioplankton and microzooplankton. When the SACW upwelled, with lower temperatures and higher nitrate contents, the autotrophic microplankton appeared, while autotrophic picoplankton, bacterioplankton and microzooplankton abundances decreased abruptly. During that period, mesozooplankton - especially the opportunist herbivorous copepods - dominated as primary consumers, characterizing the establishment of an herbivorous food web structure.

The hydrological structure of the water column, along with the concentrations of nutrients observed during the downwelling period, are a result of the combination of the oligotrophic Brazil Current Tropical Water and the continental-influenced Coastal Water (Castro \& Miranda 1998, Ito et al. 2005). The increase in the nutrient contents at the surface and $40 \mathrm{~m}$ layers during the SACW upwelling indicates fertilization of surface waters from deeper water masses and is comparable to other highly productive coastal upwelling systems (e.g. Escribano et al. 2004). In contrast, the high DOM C:N observed in both layers and periods indicates the predominance of allochthonous DOM, rich in organic carbon, probably composed of dissolved detrital material of terrestrial origin (Findlay et al. 1991).

The dominance of pico- and nanoplankton and the absence of microplankton on PB during the downwelling period, also detected in other upwelling systems (e.g. Iriarte \& Gonzalez 2004), corroborate the hypothesis that smaller cells dominate in oligotrophic and stratified conditions. The increase in PB at the surface and its decrease at $40 \mathrm{~m}$, along with the appearance of microplankton in both sampled layers during the SACW upwelling, indicate surface enrichment of phytoplankton cells from the bottom carried by deeper water masses. A simultaneous study performed in the same area showed that the microplankton community from surface upwelled waters was 90 to $100 \%$ composed of centric diatoms (Purcell 2005), similar to other coastal upwelling areas (e.g. Lassiter et al. 2006). This group usually predominates in deeper layers due to its higher sinking rates (Kiørboe 1993) and is the main component of Cabo Frio phytoplankton community near the bottom (Valentin et al. 1986). However, the SACW upwelling did not affect phytoplankton photosynthetic efficiency. Instead, irradiation seems to be the main $\mathrm{P}^{\mathrm{B}}$ limiting factor in the Cabo Frio system. The photic layer, estimated from irradiance profiles, was around $20 \mathrm{~m}$ deep during the whole study period (data not shown), which explains the lower $\mathrm{P}^{\mathrm{B}}$ at $40 \mathrm{~m}$ during both periods.

BP represented only a small fraction of total organic carbon produced - most of which was due to phytoplankton - and was lower than that observed in other upwelling systems (e.g. McManus \& Peterson 1988, Cuevas et al. 2004). This is possibly due to the DOM elemental composition at Cabo Frio. Bacterial C:N is usually around 5.0 and so must be the DOM taken up by these organisms (Goldman et al. 1987). Therefore, a DOM C:N higher than 5.0 implies an excess of carbon, which affects bacterial growth efficiency, as bacteria have to compensate the $\mathrm{C}: \mathrm{N}$ balance through inorganic N uptake (Kirchman 1994). The BP variations observed in the present study were inversely dependent on DOC concentrations at the surface and directly dependent on $\mathrm{N}-\mathrm{NO}_{2}$ at $40 \mathrm{~m}$, indicating that although the DOC pool is large, the quality of DOM may be limiting bacterial growth and, as a result, that these organisms should meet their organic $\mathrm{N}$ requirements through inorganic uptake. The steep decline in BP after the SACW upwelling, also observed in other upwelling areas (e.g. McManus \& Peterson 1988), indicates low bacterial activity in this water mass, which is 
probably due to the lower temperatures, limiting bacterial growth efficiencies (Apple et al. 2006). Experimental studies performed with Cabo Frio upwelled water demonstrated an increase in bacterial production rates $72 \mathrm{~h}$ after the maximum phytoplankton production rates, suggesting that the organic compounds released by those cells during their decline favors bacterioplankton growth (Carvalho \& GonzalezRodriguez 2004). In the present study, no coupling between BP and PP was observed, possibly due to the low phytoplankton contribution to the DOM pool (Baines \& Pace 1991). Nevertheless, it is possible that at late upwelling periods, after phytoplankton maximum growth, a higher phytoplankton exudate release would result in higher BP rates.

Bacterivory represents an important organic carbon transfer to higher trophic levels through nano- and micro-sized consumers (Azam et al. 1983). Although small heteronanoflagellates (HNF) are usually the main bacterial grazers (Strom 2000), micro-sized heterotrophs are able to consume a wide size range of both auto- and heterotrophic prey, being also significant bacterivores (Sherr \& Sherr 1987). While HNF and bacterial biomass were not measured in the present study, the higher BP rates and MiZA observed during the downwelling, along with the direct correlation between BP and MiZA at the surface ( $\mathrm{r}=0.55, \mathrm{p}=0.012)$, suggests that bacterioplankton may be supporting the microzooplankton community during that period. Moreover, microzooplankton are also important phytoplankton grazers and generally dominate mesozooplankton as primary consumers in more oligotrophic systems (Strom 2002). The direct correlations between MiZA and autotrophic picoplankton biomass in both layers (surface: $\mathrm{r}=0.60, \mathrm{p}=0.005 ; 40 \mathrm{~m}: \mathrm{r}=0.89, \mathrm{p}<$ 0.001) suggest that the high MiZA observed during this period is also sustained by the phytoplankton. This is well supported by grazing experiments performed at the same area under downwelling conditions, which showed that microzooplankton consumed, on average, $85 \%$ of phytoplankton production (McManus et al. 2007). All this indicates that the observed decline in MiZA with the SACW upwelling, also observed in other upwelling areas (e.g. McManus \& Peterson 1988), was due to resources limitation, i.e. the decrease in both auto- and heterotrophic picoplankton.

The SACW upwelling also influenced larger zooplankton dynamics. The cladoceran Pseudevadne tergestina and the copepods Paracalanus parvus and Temora turbinata, the most representative mesozooplankton species during the downwelling period, are tropical neritic species, ubiquitous along the Brazil Current warm waters (Valentin 1984b). These are omnivorous species, filter-feeding on both auto- and heterotrophic micro-sized organisms (Turner 1984,
Egloff et al. 1997, Suzuki et al. 1999), which suggest that they are possibly profiting from the high MiZA occurring during this period.

The decline in surface temperatures with the SACW upwelling led to a decrease in Temora turbinata and Pseudevadne tergestina abundances along with an increase in the abundance of cold water tolerant species: Paracalanus parvus, Ctenocalanus vanus and Calanoides carinatus. These opportunistic herbivores can achieve high growth rates induced by pulses of autotrophic microplankton biomass, typical of upwelling areas (Valentin 1984b). The observed simultaneous increase in $\mathrm{PB}$ and $P$. parvus, $C$. vanus and C. carinatus abundances is characteristic of the Cabo Frio region and owes to the short upwelling cycle duration, equivalent to the copepod lifetime. The high microplankton biomass, resulting from the the SACW upwelling, induces fast copepod spawn and larval development. These larvae, advected through the upwelling drift currents to the open sea, follow an ontogenetic migration, returning to the coastal surface water as adults on the subsequent upwelling event (Peterson et al. 1979, Valentin 1984a). These ontogenetic cycles are particularly important as PB control, and are possibly the reason why the highest $\mathrm{PB}$ in

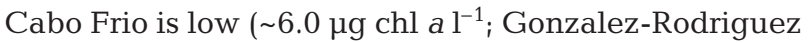
et al. 1992), compared to other upwelling systems (e.g. Montecino et al. 2004).

In summary, although the POC produced during the downwelling-upwelling cycle was essentially due to phytoplankton, the fate of this biogenic carbon may vary due to changes in planktonic trophic structure. During the downwelling period, the carbon produced by both small phytoplankton and bacteria is channeled through flagellates and ciliates before reaching the omnivores-dominant mesozooplankton species. With the SACW upwelling, auto- and heterotrophic picoplankton production decrease, and the microplankton POC produced is directly consumed by the opportunistic herbivorous copepod species. The carbon export through the pelagic food web thus seems to be more efficient during upwelling periods.

The present study demonstrates how short-term temporal variations in circulation dynamics can affect the whole trophic structure of a system, interfering directly with carbon export magnitude. These results indicate that the Cabo Frio upwelling system is characterized by a multivorous food web (Legendre \& Rassoulzadegan 1995) due to temporal shifting from microbial to herbivorous food web structures.

Acknowledgements. The authors thank the IEAPM technicians and the RV 'Diadorim' crew for laboratory and field support, Laboratório de Hidrobiologia (UFRJ) for chl a analysis, C. A. Purcell for allowing the use of microzooplankton data from her MSc thesis, L. B. Miranda and M. Araújo for helpful 
suggestions on physical data analyses, and W. T. Peterson, D. Astúa and 2 anonymous referees for important suggestions on the manuscript. Field work and analyses were supported by grants from the National Research Council (CNPq - 3306 . 188/2004-0) and the Rio de Janeiro State Research Foundation (FAPERJ - E-26/151.949/2004). M.G. was supported by doctoral fellowship from CNPq (141873/2003-5).

\section{LITERATURE CITED}

Aminot A, Chaussepied M (1983) Manuel des analyses chimiques en milieu marin. Centre National pour l'Exploitation des Oceans, Brest

Apple JK, del Giorgio PA, Kemp WM (2006) Temperature regulation of bacterial production, respiration, and growth efficiency in a temperate salt-marsh estuary. Aquat Microb Ecol 43:243-254

Azam F, Fenchel T, Field JG, Gray JS, Meyerreil LA, Thingstad F (1983) The ecological role of water-column microbes in the sea. Mar Ecol Prog Ser 10:257-263

Baines S, Pace M (1991) The production of dissolved organic matter by phytoplankton and its importance to bacteria: patterns across marine and freshwater systems. Limnol Oceanogr 36:1078-1090

Bode A, Alvarez-Ossorio MT, Barquero S, Lorenzo J, Louro A, Varela M (2003) Seasonal variations in upwelling and in the grazing impact of copepods on phytoplankton off A Coruña (Galicia, NW Spain). J Exp Mar Biol Ecol 297: 85-105

Boltovskoy D (1999) South Atlantic zooplankton. Backhuys Publishers, Leiden

Brown SL, Landry MR, Christensen S, Garrison D, Gowing MM, Bidigare RR, Campbell L (2002) Microbial community dynamics and taxon-specific phytoplankton production in the Arabian Sea during the 1995 monsoon seasons. Deep-Sea Res II 49:2345-2376

Carvalho WF, Gonzalez-Rodriguez E (2004) Development of primary and bacterial production in upwelling waters of Arraial do Cabo region, RJ (Brazil). Braz J Oceanogr 52: 35-45

Castro BM, Miranda LB (1998) Physical oceanography of the Western Atlantic continental shelf located between $4 \mathrm{~N}$ and 34 S. In: Robinson A, Brink K (eds) The sea. John Wiley \& Sons, New York, p 209-251

Collins CA, Pennington JT, Castro CG, Rago TA, Chavez FP (2003) The California Current system off Monterey, California: physical and biological coupling. Deep-Sea Res II 50:2389-2404

Cuevas LA, Daneri G, Jacob B, Montero P (2004) Microbial abundance and activity in the seasonal upwelling area off Concepcion (similar to 36 degrees S), central Chile: a comparison of upwelling and non-upwelling conditions. DeepSea Res II 51:2427-2440

Dugdale R, Goering J (1967) Uptake of new and regenerated forms of nitrogen in primary productivity. Limnol Oceanogr 12:196-206

Egloff DA, Fofonoff PW, Onbe T (1997) Reproductive biology of marine cladocerans. Adv Mar Biol 31:79-167

Escribano R, Daneri G, Farias L, Gallardo VA and others (2004) Biological and chemical consequences of the 1997-1998 El Niño in the Chilean coastal upwelling system: a synthesis. Deep-Sea Res II 51:2389-2411

> Fernandez-Alamo MA, Farber-Lorda J (2006) Zooplankton and the oceanography of the eastern tropical Pacific: a review. Prog Oceanogr 69:318-359

Findlay S, Pace ML, Lints D, Cole JJ, Caraco NF, Peierls B
(1991) Weak coupling of bacterial and algal production in a heterotrophic ecosystem: the Hudson river estuary. Limnol Oceanogr 36:268-278

Goldman J, Caron DA, Dennett M (1987) Regulation of gross growth efficiency and ammonium regeneration in bacteria substrate C:N ratio. Limnol Oceanogr 32:1239-1252

> Gonzalez-Rodriguez E, Valentin JL, Andre DL, Jacob SA (1992) Upwelling and downwelling at Cabo Frio (Brazil) comparison of biomass and primary production responses. J Plankton Res 14:289-306

Grasshoff KA, Ehrhardt M, Kremling K (1983) Methods for seawater analysis. Verlag Chemie, Weinheim

Griffiths FB, Fleminger A, Kimor B, Vanucci M (1976) Shipboard and curating techiniques. In: Steedman HF (ed) Zooplankton fixation and preservation-monographs on oceanographics methodology. UNESCO, Paris, p 17-19

Guenther M, Bozelli R (2004) Factors influencing algae-clay aggregation. Hydrobiologia 523:217-223

Iriarte JL, Gonzalez HE (2004) Phytoplankton size structure during and after the 1997/98 El Nino in a coastal upwelling area of the northern Humboldt Current System. Mar Ecol Prog Ser 269:83-90

Ito RG, Schneider B, Thomas H (2005) Distribution of surface $\mathrm{fCO}_{2}$ and air-sea fluxes in the Southwestern subtropical Atlantic and adjacent continental shelf. J Mar Syst 56: $227-242$

Kiørboe T (1993) Turbulence, phytoplankton cell size, and the structure of pelagic food webs. Adv Mar Biol 29:1-72

> Kirchman DL (1994) The uptake of inorganic nutrients by heterotrophic bacteria. Microb Ecol 28:255-271

Lancelot C (1979) Gross excretion rates of natural marinephytoplankton and heterotrophic uptake of excreted products in the southern North Sea, as determined by shortterm kinetics. Mar Ecol Prog Ser 1:179-186

Lassiter AM, Wilkerson FP, Dugdale RC, Hogue VE (2006) Phytoplankton assemblages in the COOP-WEST coastal upwelling area. Deep-Sea Res II 53:3063-3077

Legendre L, Le Fevre J (1995) Microbial food webs and the export of biogenic carbon in oceans. Aquat Microb Ecol 9:69-77

Legendre L, Rassoulzadegan F (1995) Plankton and nutrients dynamics in marine waters. Ophelia 41:153-172

Legendre L, Rassoulzadegan F (1996) Food-web mediated export of biogenic carbon in oceans: hydrodynamic control. Mar Ecol Prog Ser 145:179-193

Li WKW, Platt T (1987) Photosynthetic picoplankton in the ocean. Sci Prog 71:117-132

Malone TC (1980) Algal size. In: Morris I (ed) The physiological ecology of phytoplankton. Blackwell Scientific Publications, London, p 433-463

McManus GB, Peterson WT (1988) Bacterioplankton production in the nearshore zone during upwelling off central Chile. Mar Ecol Prog Ser 43:11-17

> McManus GB, Costas BA, Dam HG, Lopes RN, Gaeta SA, Susini SM, Rosetta CH (2007) Microzooplankton grazing of phytoplankton in a tropical upwelling region. Hydrobiologia 575:69-81

Montecino V, Astoreca R, Alarcon G, Retamal L, Pizarro G (2004) Bio-optical characteristics and primary productivity during upwelling and non-upwelling conditions in a highly productive coastal ecosystem off central Chile (similar to 36 degrees S). Deep-Sea Res II 51:2413-2426

Parsons TR, Maita Y, Lalli CM (1984) A manual of chemical and biological methods for seawater analysis. Pergamon Press, Oxford

$>$ Peterson WT, Miller CB, Hutchinson A (1979) Zonation and maintenance of copepod populations in the Oregon up- 
welling zone. Deep-Sea Res I 26:467-494

Peterson WT, Arcos DF, McManus GB, Dam H, Bellantoni D, Johnson T, Tiselius P (1988) The nearshore zone during coastal upwelling - daily variability and coupling between primary and secondary production off central Chile. Prog Oceanogr 20:1-40

Price NM, Cochlan WP, Harrison PJ (1985) Time course of uptake of inorganic and organic nitrogen by phytoplankton in the Strait of Georgia - comparison of frontal and stratified communities. Mar Ecol Prog Ser 27:39-53

Purcell CA (2005) Biomassa e produção primária fracionadas (pico-, nano- e microfitoplâncton), e a contribuição relativa do compartimento heterotrófico à biomassa microplanctônica na ressurgência de Cabo Frio (RJ). MSc thesis, Univ. São Paulo

Shannon CE (1948) A mathematical theory of communication. Bell Syst Tech J 27:379-423 \& 623-656

Sherr EB, Sherr BF (1987) High-rates of consumption of bacteria by pelagic ciliates. Nature 325:710-711

Sherr EB, Sherr BF (1993) Preservation and storage of samples for enumeration of heterotrophic protists. In: Kemp PF, Sherr BF, Sherr EB, Cole JJ (eds) Handbook of methods in aquatic microbial ecology. Lewis Publishers, Boca Raton, FL, p 207-212

Sherr EB, Sherr BF, Paffenhofer GA (1986) Phagotrophic protozoa as food for metazoans: a 'missing' trophic link in marine pelagic food webs? Mar Microb Food Webs 1: $61-80$

Silva AC, Araújo M, Bourles B (2005) Variação sazonal da estrutura de massas de água na plataforma continental do Amazonas e área oceânica adjacente. Braz J Geophys 23:1-13

Simon M, Azam F (1989) Protein-content and protein-synthesis rates of planktonic marine-bacteria. Mar Ecol Prog Ser 51:201-213

Editorial responsibility: William Peterson, Newport, Oregon, USA
Smith D, Azam F (1992) A simple, economical method for measuring bacterial protein synthesis rates in seawater using ${ }^{3} \mathrm{H}$-leucine. Mar Microb Food Webs 6:107-114

Steemann-Nielsen E (1952) The use of radio-active carbon $\left({ }^{14} \mathrm{C}\right)$ for measuring organic production in the sea. J Cons Int Explor Mer 18:117-140

Strom SL (2000) Bacterivory: interactions between bacteria and their grazers. In: Kirchman DL (ed) Microbial ecology of the oceans. Wiley-Liss, New York, p 351-386

Strom SL (2002) Novel interactions between phytoplankton and microzooplankton: their influence on the coupling between growth and grazing rates in the sea. Hydrobiologia 480:41-54

Suzuki K, Nakamura Y, Hiromi J (1999) Feeding by the small calanoid copepod Paracalanus sp. on heterotrophic dinoflagellates and ciliates. Aquat Microb Ecol 17:99-103

Turner JT (1984) Zooplankton feeding ecology — contents of fecal pellets of the copepods Temora turbinata and Temora stylifera from continental-shelf and slope waters near the mouth of the Mississippi river. Mar Biol 82:73-83

Utermöhl H (1958) Zur Vervollkommnung der quantitativen Phytoplankton-Methodik. Mitt Int Verein Theor Angew Limnol 9:1-38

Valentin JL (1984a) Analyse des paramètres hydrobiologiques dans la remontée de Cabo Frio (Brésil). Mar Biol 82:259-276

> Valentin JL (1984b) Spatial structure of the zooplankton community in the Cabo Frio region (Brazil) influenced by coastal upwelling. Hydrobiologia 113:183-199

Valentin JL, Lins da Silva NM, Monteiro-Ribas WM, Mureb MA and others (1986) Le plancton dans l'upwelling de Cabo Frio (Brésil): microrépartition spatio-temporelle à une station fixe. Ann Inst Oceanogr Paris (Nouv Ser) 62:117-135

Submitted: November 22, 2007; Accepted: February 25, 2008 Proofs received from author(s): June 1, 2008 